Check for updates

Cite this: RSC Adv., 2019, 9, 12567

Received 20th March 2019

Accepted 15th April 2019

DOI: $10.1039 / c 9 r a 02144 b$

rsc.li/rsc-advances

\section{Synthesis of poly-functionalized benzofurans via one-pot domino oxidation/[3+2] cyclization reactions of a hydroquinone ester and ynamides $\uparrow$}

\author{
Dongxin Zhang, D * Jingjing Man, Yan Chen, Lei Yin, Junchao Zhong \\ and Qian-Feng Zhang*
}

Densely substituted amino-functionalized benzofurans were concisely accessed via the first one-pot domino oxidation/[3+2] cyclization of a hydroquinone ester and easily accessible ynamides under mild conditions in a short time. The complex benzofurans were able to be efficiently synthesized all from simple and inexpensive starting materials in two steps.
Benzofuran derivatives are valuable structural motifs that are often found in natural products and biologically active compounds. ${ }^{1}$ Various methods have been developed for the synthesis of those heterocyclic scaffolds, ${ }^{2,3}$ among which the intramolecular annulation of preformed ortho-alkynylated phenols catalyzed by transition metals is the most general way. ${ }^{2 e-o}$ Recently, Li and coworkers reported a novel ironcatalyzed tandem oxidative coupling and annulation process to access benzofurans from simple phenols and $\beta$-keto esters (Scheme 1a), ${ }^{3 a}$ and the group of Dominguez disclosed a onepot approach to benzofurans from 2-hydroxybenzophenones and $N, N$-dimethylacetamide promoted by copper under oxidative conditions (Scheme 1b). ${ }^{3 b}$ Both of the two methods provided direct access to benzofuran derivatives from simple easy accessible starting materials under oxidative conditions, but all the reactions were performed at high temperature and with relatively high catalyst loading. Fast reactions under mild conditions are undoubtedly more desirable. In this context, we report the direct synthesis of densely substituted benzofurans from simple and inexpensive starting materials via the first one-pot domino oxidation/[3+2] cyclization of a hydroquinone derivative and ynamides under mild conditions (Scheme 1c).

Over the past decades, ynamides, as powerful synthons, have been involved in the transition-metal catalyzed cyclization reactions for the construction of diverse building blocks of functionalized molecules including important pharmacophores. ${ }^{4}$ Although various cyclic systems have been achieved via the reactions of ynamides, ${ }^{4 a-q}$ to the best of our knowledge,

Institute of Molecular Engineering and Applied Chemistry, Anhui University of Technology, No. 59 Hudong Road, Ma'anshan 243002, China. E-mail: dxzhang@ ahut.edu.cn; zhangqf@ahut.edu.cn

$\dagger$ Electronic supplementary information (ESI) available: Experimental details, characterization data of reactants and products, and copies of NMR spectroscopy. See DOI: 10.1039/c9ra02144b construction of amino-functionalized benzofurans from ynamides have not been reported. Therefore, we initiated our design to access benzofuran derivatives via the [3+2] cyclizations of ynamides with quinones. Quinones can be easily oxidized from hydroquinones, which provides the possibility for coupling the oxidation and cyclization into a one-pot domino process. $^{5,6 b}$ Before coupling the two steps together, we first chose to optimize the cyclization step.

First, we started the investigation with ynamide 1a and quinone 2a. Lewis acids have been reported as good activators

a) Li's work : Iron-Catalyzed Tandem Oxidative Coupling and Annulation

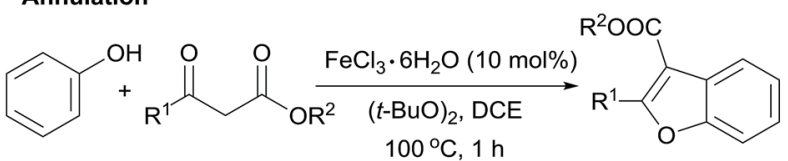

DCE $=$ dichloroethane

b) Dominguez's work: Copper Promoted Cascade Reactions Under Oxidative Conditions

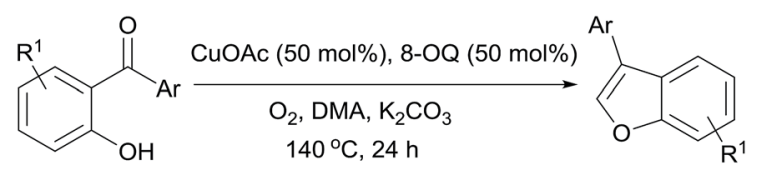

8-OQ = 8-hydroxyquinoline; $\mathrm{DMA}=\mathrm{N}, \mathrm{N}$-dimethylacetamide

c) This work: One-pot Domino Oxidation/[3+2] Cycloaddition<smiles>[R]C#CN([R])C(C)(C)C</smiles>

$E W G=$ electron withdrawing group

Scheme 1 Direct accesses to benzofuran derivatives under oxidative conditions. 
of quinones. ${ }^{6,7 a}$ However, by the use of Lewis acid $\mathrm{Sc}(\mathrm{OTf})_{3}$ as the catalyst, there was no desired benzofuran product formation at all while the ynamide hydrolysis byproduct $\mathbf{4 a}$ formed exclusively (Table 1, entry 1). Attempts by the addition of $4 \AA$ molecular sieves and carrying out the reaction under inert atmosphere suppressed the hydrolysis somehow with still no product formation (Table 1, entry 2). To overcome the low reactivity problem of $\mathbf{2 a}$ and the hydrolysis problem of $\mathbf{1 a}$, we pursued to improve the reactivity of quinone by installing an ester group on the quinone ring, which may enhance its electrophilicity. ${ }^{7}$ Quinone ester $\mathbf{2 b}$ was easily synthesized via oxidation of commercially available methyl 2,5-dihydroxybenzoate (5). Gratifyingly, the reaction of $\mathbf{1 a}$ with quinone ester $2 \mathbf{b}$ catalyzed by $\mathrm{Sc}(\mathrm{OTf})_{3}$ afforded the desired $[3+2]$ cyclization product 3a in $89 \%$ yield within 5 min with only trace amount of hydrolysis product detected (Table 1, entry 3 ). By the use of $\mathrm{Cu}(\mathrm{OTf})_{2}$ as the catalyst, in $5 \mathrm{~min}$ the reaction of 1a and $2 \mathbf{b}$ afforded both $\mathbf{3 a}$ and $\mathbf{4 a}$, in $61 \%$ and $18 \%$ yield respectively (Table 1 , entry 4$). \mathrm{Yb}(\mathrm{OTf})_{3}$ also catalyzed the reaction efficiently with small amount of $\mathbf{4 a}(4 \%)$ formation (Table 1 , entry 5). Other Lewis acids, such as $\mathrm{AlCl}_{3}$ could catalyze the reaction to afford $3 \mathbf{3}$ with no $\mathbf{4 a}$ formation though the efficiency is much lower than that of $\mathrm{Sc}(\mathrm{OTf})_{3}$ (Table 1, entry 6). Screening of a small set of solvents indicated that $\mathrm{CH}_{2} \mathrm{Cl}_{2}$ was the most suitable solvent for this [3+2] cyclization (Table 1, entries 7 and 8). Reducing the amount of $2 \mathbf{b}$ from 1.5 equiv. to 1.2 equiv. did not affect the reaction efficiency and product 3a was obtained in 90\% yield (Table 1, entry 9). As expected, when excess amount of 1a was used, product 3a was formed along with small amount of $\mathbf{4 a}$ (Table 1, entry 10). The catalyst loading could be reduced to $5 \mathrm{~mol} \%$, even $2 \mathrm{~mol} \%$ without significant negative effect for the efficiency of the $[3+2]$ cyclization (Table 1, entries 11 and 12).

With the best cyclization reaction conditions in hand, next we tried to combine the oxidation step with the $[3+2]$ cyclization into a one-pot domino process. ${ }^{5 \boldsymbol{a}}$ Hydroquinone ester $\mathbf{5}$ was first mixed with oxidant $\mathrm{Ag}_{2} \mathrm{O}$ and $\mathrm{MgSO}_{4}$ in $\mathrm{CH}_{2} \mathrm{Cl}_{2}$ and the mixture was stirred for $2 \mathrm{~h}$. Then $1 \mathrm{a}$ and $\mathrm{Sc}(\mathrm{OTf})_{3}$ were directly added to the above mixture. ${ }^{\mathbf{8 9}}$ To our delight, the one-pot domino oxidation/[3+2] cyclization occurred efficiently, affording $\mathbf{3 a}$ in $91 \%$ yield (Table 1, entry 13 ). The one-pot process provided the densely substituted benzofuran (3a) in a step-economy manner. Next, for the substrate scope exploration, the one-pot domino process was employed (Scheme 2).

In general, the reactions of $\mathbf{5}$ with a series of ynamides in the one-pot system afforded poly-substituted benzofurans 3 in good to excellent yields (85-96\%). Ynamides with both aromatic and alkyl groups at the terminal position could be tolerated, furnishing 3-aromatic or 3-alkyl substituted benzofurans with high yields (Scheme 2). The reactions of alkyl-terminated ynamides gave slightly higher yields than that of aromatic-

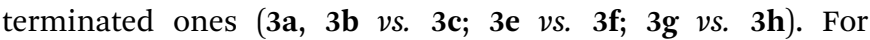

Table 1 Optimization of the reaction conditions ${ }^{a}$

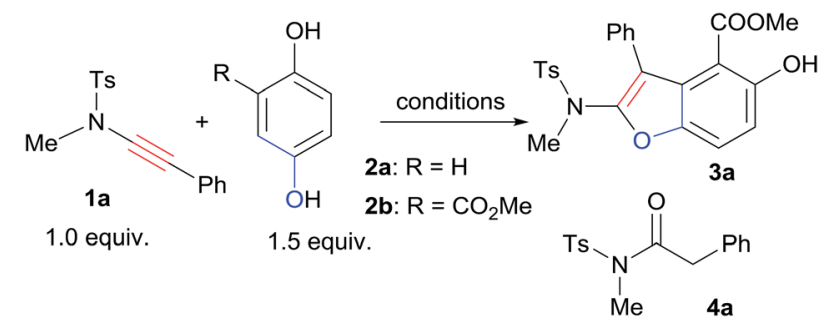

\begin{tabular}{|c|c|c|c|c|c|c|}
\hline Entry & Catalyst (10 mol\%) & Solvent & $\mathrm{R}$ & Time & $\operatorname{Yield}^{b}(\mathbf{3 a})[\%]$ & Yield $^{b}(\mathbf{4 a})[\%]$ \\
\hline 1 & $\mathrm{Sc}(\mathrm{OTf})_{3}$ & $\mathrm{CH}_{2} \mathrm{Cl}_{2}$ & $\mathrm{H}$ & $5 \mathrm{~min}$ & - & 91 \\
\hline $2^{c}$ & $\mathrm{Sc}(\mathrm{OTf})_{3}$ & $\mathrm{CH}_{2} \mathrm{Cl}_{2}$ & $\mathrm{H}$ & $2 \mathrm{~h}$ & - & 33 \\
\hline 4 & $\mathrm{Cu}(\mathrm{OTf})_{2}$ & $\mathrm{CH}_{2} \mathrm{Cl}_{2}$ & $\mathrm{CO}_{2} \mathrm{Me}$ & $5 \mathrm{~min}$ & 61 & 18 \\
\hline 5 & $\mathrm{Yb}(\mathrm{OTf})_{3}$ & $\mathrm{CH}_{2} \mathrm{Cl}_{2}$ & $\mathrm{CO}_{2} \mathrm{Me}$ & $5 \mathrm{~min}$ & 83 & 4 \\
\hline 6 & $\mathrm{AlCl}_{3}$ & $\mathrm{CH}_{2} \mathrm{Cl}_{2}$ & $\mathrm{CO}_{2} \mathrm{Me}$ & $30 \mathrm{~min}$ & 33 & Trace \\
\hline $9^{d}$ & $\mathrm{Sc}(\mathrm{OTf})_{3}$ & $\mathrm{CH}_{2} \mathrm{Cl}_{2}$ & $\mathrm{CO}_{2} \mathrm{Me}$ & $5 \mathrm{~min}$ & 90 & Trace \\
\hline $10^{e}$ & $\mathrm{Sc}(\mathrm{OTf})_{3}$ & $\mathrm{CH}_{2} \mathrm{Cl}_{2}$ & $\mathrm{CO}_{2} \mathrm{Me}$ & $5 \mathrm{~min}$ & $88^{f}$ & 9 \\
\hline $11^{d, g}$ & $\mathrm{Sc}(\mathrm{OTf})_{3}$ & $\mathrm{CH}_{2} \mathrm{Cl}_{2}$ & $\mathrm{CO}_{2} \mathrm{Me}$ & $5 \mathrm{~min}$ & 91 & Trace \\
\hline $12^{d, h}$ & $\mathrm{Sc}(\mathrm{OTf})_{3}$ & $\mathrm{CH}_{2} \mathrm{Cl}_{2}$ & $\mathrm{CO}_{2} \mathrm{Me}$ & $5 \mathrm{~min}$ & 88 & Trace \\
\hline $13^{d, h, i}$ & $\mathrm{Sc}(\mathrm{OTf})_{3}$ & $\mathrm{CH}_{2} \mathrm{Cl}_{2}$ & $\mathrm{CO}_{2} \mathrm{Me}$ & $5 \mathrm{~min}$ & 91 & Trace \\
\hline
\end{tabular}

${ }^{a}$ Unless otherwise noted, reactions were carried out using ynamide $1 \mathrm{a}(0.10 \mathrm{mmol}), 2(0.15 \mathrm{mmol})$ with catalyst $(0.01 \mathrm{mmol})$ in solvent $2.0 \mathrm{~mL}$ at room temperature $\left(25^{\circ} \mathrm{C}\right)$ in air. ${ }^{b}$ Isolated yields relative to $1 \mathrm{a} .{ }^{c} 100 \mathrm{mg} 4 \AA$ molecular sieves were added and under Ar atmosphere. ${ }^{d} 2 \mathbf{b}(0.12$ mmol) was used. ${ }^{e} \mathbf{1 a}(0.12 \mathrm{mmol}), \mathbf{2 b}(0.10 \mathrm{mmol})$ was used. ${ }^{f}$ Yield relative to $2 \mathbf{b} .{ }^{g}$ Catalyst $(0.005 \mathrm{mmol})$ was used. ${ }^{h}$ Catalyst $(0.002 \mathrm{mmol})$ was used. ${ }^{i}$ Hydroquinone ester $5(0.12 \mathrm{mmol}), \mathrm{Ag}_{2} \mathrm{O}(0.24 \mathrm{mmol})$, and $\mathrm{MgSO}_{4}(0.24 \mathrm{mmol})$ were mixed in $\mathrm{CH}_{2} \mathrm{Cl}_{2}(2.0 \mathrm{~mL})$ and the mixture was stirred for $2 \mathrm{~h}$, and then $1 \mathrm{a}(0.10 \mathrm{mmol})$ and $\mathrm{Sc}(\mathrm{OTf})_{3}(0.002 \mathrm{mmol})$ were added. 
<smiles>[R]C#CN([R])C(C)=O</smiles><smiles>CC(=O)c1c(O)ccc2oc(N([13CH3])[13CH3])c(C(C)=O)c12</smiles>

3a, $91 \%$<smiles>CC(=O)c1c(O)ccc2oc(N(C)[13CH3])c([13CH3])c12</smiles><smiles>CC(=O)c1c(O)ccc2oc(N3CCC3=O)c([14CH3])c12</smiles><smiles>CC(=O)c1c(O)ccc2oc(N3CCC3=O)c(-c3ccccc3)c12</smiles>

3f, $91 \%$<smiles>COc1ccc(-c2c(N(C)[18OH])oc3ccc(O)c(C(C)=O)c23)cc1</smiles><smiles>CC(=O)c1c(O)ccc2oc(N([13CH3])[13CH3])c(S[13CH3])c12</smiles><smiles>CC(=O)c1c(O)ccc2oc(-c3ccccc3)c(C(C)=O)c12</smiles>

3h, $96 \%$

Scheme 2 Substrate scope of the one-pot domino oxidation/[3+2] cyclization reaction. Reaction conditions: hydroquinone ester 5 (0.12 $\mathrm{mmol}), \mathrm{Ag}_{2} \mathrm{O}(0.24 \mathrm{mmol})$, and $\mathrm{MgSO}_{4}(0.24 \mathrm{mmol})$ were mixed in $\mathrm{CH}_{2} \mathrm{Cl}_{2}(2.0 \mathrm{~mL})$ and the mixture was stirred for $2 \mathrm{~h}$, and then $1(0.10$ $\mathrm{mmol})$ and $\mathrm{Sc}(\mathrm{OTf})_{3}(0.002 \mathrm{mmol})$ were added.

ynamides with sulfonyl system, the triisopropylsilyl-terminated ynamide was successfully applied in the one-pot reaction, and the desired product $3 \mathrm{~d}$ was obtained in $85 \%$ yield. The reactions of ynamides with propiolactam system also worked well to give 3e $(85 \%)$ and 3 f $(91 \%)$. Ynamides derived from indole ester reacted well with 5 in this one-pot system, giving rise to the interesting 1-benzofuranyl indole derivatives $(\mathbf{3 g}, \mathbf{3 h})$ in perfect yields, $90 \%$ and $96 \%$ respectively.

It is worth to mention that ynamides (1) used here were all easily prepared in one step via copper-catalyzed oxidative cross coupling of corresponding simple amides and terminal alkynes according to literature procedures, ${ }^{4 q, 10}$ which indicates that the complex poly-functionalized benzofurans (3) were able to be efficiently synthesized all from simple and inexpensive staring materials in only two steps (Scheme 3). A large scale reaction was performed to synthesize 1-benzofuranyl indole $\mathbf{3 h}$. Starting from simple commercial available 1-heptyne, methyl indole-3-carboxylate, and methyl 2,5-dihydroxybenzoate (5), $1.64 \mathrm{~g}$ of $\mathbf{3 h}$ was obtained in two steps with high efficiency (Scheme 3b).

The postulated mechanisms resulting in the formation of densely substituted benzofurans 3 are proposed as shown in Scheme 4. Hydroquinone 5 is first oxidized by $\operatorname{Ag}_{2} \mathrm{O}$ to give

a)

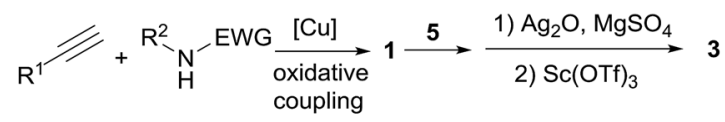

Simple and inexpensive starting materials: alkynes, amides, and $\mathbf{5}$

b)

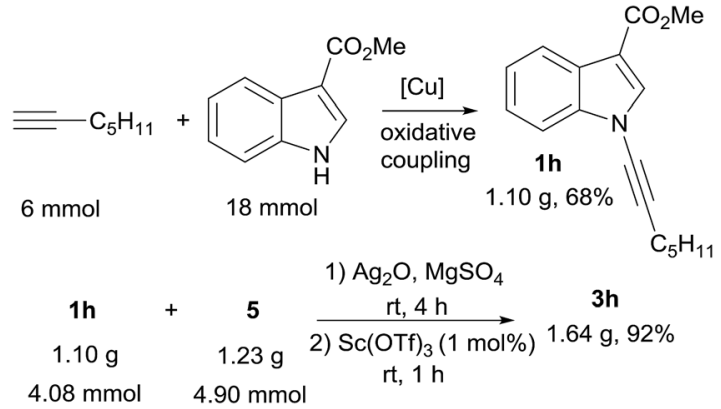

Scheme 3 (a) Concise access to complex benzofurans from simple and inexpensive starting materials. (b) A large scale reaction for the synthesis of $3 \mathrm{~h}$.

quinone ester $\mathbf{2 b}$, which is subsequently activated by $\mathrm{Sc}(\mathrm{OTf})_{3}$. According to Johnson et al. ${ }^{4 q}$ ynamides may also be functioned by the scandium Lewis acid to increase the nucleophilicity. A undergoes nucleophilic attack by the ynamide to give keteniminium ion $\mathbf{B}$. Then, 1,2-proton shift followed by the intramolecular cyclization of $\mathbf{B}$ furnishes intermediate C. Finally, after tautomerization and release of $\mathrm{Sc}(\mathrm{OTf})_{3}$, desired product 3 is formed.

In summary, we have developed a fast and step-economical one-pot domino oxidation $/[3+2]$ cyclization reactions of a hydroquinone ester and ynamides. A series of densely functionalized benzofurans were concisely achieved in good to excellent yields from simple and inexpensive starting materials under mild conditions. A gram scale reaction proved that the one-pot reaction was able to be scaled up easily. Further studies on the expansion of the reaction scope and on the

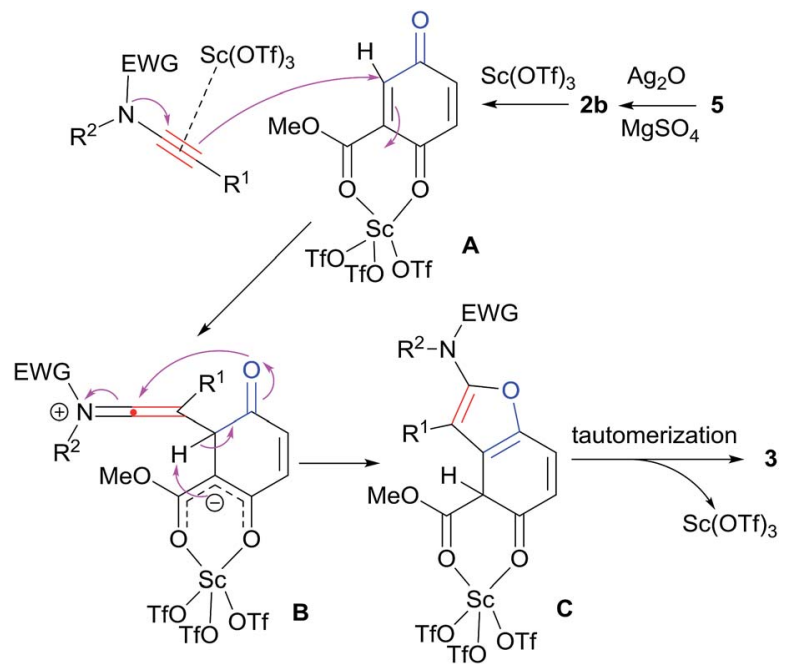

Scheme 4 Proposed mechanism for the one-pot domino oxidation/ [3+2] cyclization. 
construction of other heterocycles based on the domino strategy used in this study are ongoing and will be reported in due course.

\section{Conflicts of interest}

There are no conflicts to declare.

\section{Acknowledgements}

This study was supported by Anhui Provincial Natural Science Foundation (No. 1908085MB33) and the Anhui University of Technology.

\section{Notes and references}

1 For recent reviews and examples: (a) K. Chand, Rajeshwari, A. Hiremathad, M. Singh, M. A. Santos and R. S. Keri, Pharmacol. Rep., 2017, 69, 281; (b) A. Soleimani, J. Asadi, F. Rostami-Charati and R. Gharaei, Comb. Chem. High Throughput Screening, 2015, 18, 505; (c) A. Radadiya and A. Shah, Eur. J. Med. Chem., 2015, 97, 356; (d) R. Naik, D. S. Harmalkar, X. Xu, K. Jang and K. Lee, Eur. J. Med. Chem., 2015, 90, 379; (e) H. Khanam and Shamsuzzaman, Eur. J. Med. Chem., 2015, 97, 483; $(f)$ M. Mostofi, G. Mohammadi Ziarani and N. Lashgari, Bioorg. Med. Chem., 2018, 26, 3076; (g) B. Lu, S. Huang, J. Cao, Q. Hu, R. Shen, H. Wan, D. Wang, J. Yuan, L. Zhang, J. Zhang, M. Zhang, W. Tao and L. Zhang, Bioorg. Med. Chem., 2018, 26, 581; (h) P. Kushwaha, A. K. Tripathi, S. Gupta, P. Kothari, A. Upadhyay, N. Ahmad, T. Sharma, M. I. Siddiqi, R. Trivedi and K. V. Sashidhara, Eur. J. Med. Chem., 2018, 156, 103; (i) M. Thevenin, S. Thoret, P. Grellier and J. Dubois, Bioorg. Med. Chem., 2013, 21, 4885; (j) J. J. La Clair, A. L. Rheingold and M. D. Burkart, J. Nat. Prod., 2011, 74, 2045; (k) J. Sakurai, T. Oguchi, K. Watanabe, H. Abe, S. Kanno, M. Ishikawa and T. Katoh, Chem.-Eur. J., 2008, 14, 829; (l) R. Romagnoli, P. G. Baraldi, M. D. Carrion, C. L. Cara, O. Cruz-Lopez, M. Tolomeo, S. Grimaudo, A. Di Cristina, M. R. Pipitone, J. Balzarini, N. Zonta, A. Brancale and E. Hamel, Bioorg. Med. Chem., 2009, 17, 6862-6871.

2 For representative reviews and examples: $(a)$ N. T. Patil and Y. Yamamoto, Chem. Rev., 2008, 108, 3395; (b) A. R. Katritzky, C. N. Fali and J. Li, J. Org. Chem., 1997, 62, 8205; (c) K. C. Nicolaou, S. A. Snyder, A. Bigot and J. A. Pfefferkorn, Angew. Chem., Int. Ed., 2000, 39, 1093; (d) M. Rueping, M. Leiendecker, A. Das, T. Poisson and L. Bui, Chem. Commun., 2011, 47, 10629; (e) M. C. Willis, D. Taylor and A. T. Gillmore, Org. Lett., 2004, 6, 4755; $(f)$ H. Zhang, E. M. Ferreira and B. M. Stoltz, Angew. Chem., Int. Ed., 2004, 43, 6144; (g) A. Furstner and P. W. Davies, J. Am. Chem. Soc., 2005, 127, 15024; (h) T. Ishikawa, T. Miyahara, M. Asakura, S. Higuchi, Y. Miyauchi and S. Saito, Org. Lett., 2005, 7, 1211; (i) K. W. Anderson, T. Ikawa, R. E. Tundel and S. L. Buchwald, J. Am. Chem. Soc., 2006, 128, 10694; (j) M. A. Honey, A. J. Blake,
I. B. Campbell, B. D. Judkins and C. J. Moody, Tetrahedron, 2009, 65, 8995; (k) F. Q. Yuan and F. S. Han, Adv. Synth. Catal., 2013, 355, 537; (l) W. Hu, M. Li, G. Jiang, W. Wu and H. Jiang, Org. Lett., 2018, 20, 3500; ( $m$ ) Y. Shen, X. X. Wu, S. Chen, Y. Xia and Y. M. Liang, Chem. Commun., 2018, 54, 2256; (n) G. Deng, M. Li, K. Yu, C. Liu, Z. Liu, S. Duan, W. Chen, X. Yang, H. Zhang and P. J. Walsh, Angew. Chem., Int. Ed., 2019, 58, 2826; (o) B. Kalvacherla, S. Batthula, S. Balasubramanian and R. K. Palakodety, Org. Lett., 2018, 20, 3824.

3 (a) X. Guo, R. Yu, H. Li and Z. Li, J. Am. Chem. Soc., 2009, 131, 17387; (b) M. J. Moure, R. SanMartin and E. Dominguez, Angew. Chem., Int. Ed., 2012, 51, 3220.

4 For selected examples: (a) J. R. Dunetz and R. L. Danheiser, J. Am. Chem. Soc., 2005, 127, 5776; (b) M. Movassaghi, M. D. Hill and O. K. Ahmad, J. Am. Chem. Soc., 2007, 129, 10096; (c) P. Y. Yao, Y. Zhang, R. P. Hsung and K. Zhao, Org. Lett., 2008, 10, 4275; (d) J. Cao, Y. Xu, Y. Kong, Y. Cui, Z. Hu, G. Wang, Y. Deng and G. Lai, Org. Lett., 2012, 14, 38; (e) W. Gati, M. M. Rammah, M. B. Rammah, F. Couty and G. Evano, J. Am. Chem. Soc., 2012, 134, 9078; (f) P. R. Walker, C. D. Campbell, A. Suleman, G. Carr and E. A. Anderson, Angew. Chem., Int. Ed., 2013, 52, 9139; $(g)$ L. Zhu, Y. Yu, Z. Mao and X. Huang, Org. Lett., 2015, 17, 30; (h) H. Liu, Y. Yang, S. Wang, J. Wu, X. N. Wang and J. Chang, Org. Lett., 2015, 17, 4472; (i) A. D. Gillie, R. J. Reddy and P. W. Davies, Adv. Synth. Catal., 2016, 358, 226; (j) H. Liu, Y. Yang, J. Wu, X. N. Wang and J. Chang, Chem. Commun., 2016, 52, 6801; (k) R. N. Straker, Q. Peng, A. Mekareeya, R. S. Paton and E. A. Anderson, Nat. Commun., 2016, 7, 10109; (l) J. Zhang, Q. Zhang, B. Xia, J. Wu, X. N. Wang and J. Chang, Org. Lett., 2016, 18, 3390; (m) L.-G. Xie, S. Niyomchon, A. J. Mota, L. González and N. Maulide, Nat. Commun., 2016, 7, 10914; (n) Z. Zeng, H. Jin, X. Song, Q. Wang, M. Rudolph, F. Rominger and A. S. K. Hashmi, Chem. Commun., 2017, 53, 4304; (o) Z. Zeng, H. Jin, J. Xie, B. Tian, M. Rudolph, F. Rominger and A. S. K. Hashmi, Org. Lett., 2017, 19, 1020; (p) K. H. Oh, J. G. Kim and J. K. Park, Org. Lett., 2017, 19, 3994; (q) W. D. Mackay, M. Fistikci, R. M. Carris and J. S. Johnson, Org. Lett., 2014, 16, 1626For leading reviews: (r) K. A. DeKorver, H. Li, A. G. Lohse, R. Hayashi, Z. Lu, Y. Zhang and R. P. Hsung, Chem. Rev., 2010, 110, 5064; $(s)$ G. Evano, A. Coste and K. Jouvin, Angew. Chem., Int. Ed., 2010, 49, 2840; $(t)$ X. N. Wang, H. S. Yeom, L. C. Fang, S. He, Z. X. Ma, B. L. Kedrowski and R. P. Hsung, Acc. Chem. Res., 2014, 47, 560.

5 (a) X. L. Jiang, S. J. Liu, Y. Q. Gu, G. J. Mei and F. Shi, $A d v$. Synth. Catal., 2017, 359, 3341; (b) B. Wu, X. Gao, Z. Yan, M. W. Chen and Y. G. Zhou, Org. Lett., 2015, 17, 6134.

6 (a) C. Shu, L. H. Liao, Y. J. Liao, X. Y. Hu, Y. H. Zhang, W. C. Yuan and X. M. Zhang, Eur. J. Org. Chem., 2014, 4467; (b) L. F. Wang, Z. M. Han and R. H. Fan, Adv. Synth. Catal., 2010, 352, 3230.

7 (a) Q. J. Liu, J. Zhu, X. Y. Song, L. Wang, S. R. Wang and Y. Tang, Angew. Chem., Int. Ed., 2018, 57, 3810; (b) 
Y. H. Chen, D. J. Cheng, J. Zhang, Y. Wang, X. Y. Liu and B. Tan, J. Am. Chem. Soc., 2015, 137, 15062.

8 When all the starting materials were added at the same time, the ynamide hydrolysis product 4 a was detected and no desired product $\mathbf{3 a}$ formation.
$9 \mathrm{MgSO}_{4}$ was used to absorb water generated from the oxidation of hydroquinone. And in the one-pot system, excess amount of $\mathrm{MgSO}_{4}$ may help to attenuate the hydrolysis of the ynamide.

10 T. Hamada, X. Ye and S. S. Stahl, J. Am. Chem. Soc., 2008, 130, 833. 